\title{
MEGALIT DAN KUBUR TEMPAYAN DATARAN TINGGI JAMBI DALAM PANDANGAN ARKEOLOGI DAN ETNOSEJARAH ${ }^{1}$
}

\section{MEGALITH AND JAR BURIAL OF THE JAMBI HIGHLAND IN ARCHAEOLOGY AND ETHNOHISTORY}

\author{
Tri Marhaeni S. Budisantosa \\ Balai Arkeologi Palembang \\ Jl. Kancil Putih, Lrg. Rusa, Demang Lebar Daun, Palembang \\ marhaeni tri@yahoo.co.id
}

\begin{abstract}
One aspect of archaeological studies in highland of Jambi is ideology or belief existing within human mind. The ideology of the past society is not appeared directly through material culture. The ideological research, therefore, could approach closer to cultural system of the past with the supported by the endorsement of historical and ethnographical data of local community. This writing discusses development of such model to disclose the beliefs that playing a part in the construction of megaliths and burial jars in highland of Jambi. The problem is answered by relate the results of the discussion of archaeological data and ehtnohistorical data. Results of the discussion revealed that the archaeological data interpretation is supported by the etnhohistorical data.
\end{abstract}

Keywords: Megalith, Burial jars, Belief, Historical data, Ethnographical data

\begin{abstract}
ABSTRAK
Salah satu aspek penelitian arkeologi di dataran tinggi Jambi adalah ideologi atau kepercayaan yang terdapat dalam alam pikiran manusia. Ideologi masyarakat masa lalu tidak dapat diketahui secara langsung melalui budaya material. Oleh karena itu, penelitian ideologi dapat terungkap lebih mendekati sistem budaya masa lalu dengan dukungan data etnosejarah dari komunitas setempat. Tulisan ini membahas pengembangan model penelitian seperti itu untuk mengungkap kepercayaan yang berperan dalam pembuatan megalit dan kubur tempayan di dataran tinggi Jambi. Permasalahan tersebut dijawab dengan mengkaitkan antara hasil pembahasan data arkeologi dan data etnosejarah. Hasil pembahasan mengungkapkan bahwa penafsiran data arkeologi didukung oleh data etnosejarah.
\end{abstract}

Kata Kunci: Megalit, Kubur tempayan, Kepercayaan, Data sejarah, Data etnografi

Tanggal masuk : 20 Februari 2015

Tanggal diterima : 28 April 2015

\footnotetext{
${ }^{1}$ Makalah ini pernah dipresentasikan dalam Diskusi Ilmiah Arkeologi yang diselenggarakan oleh Ikatan Ahli Arkeologi Indonesia Komisaris Daerah Sumatera Bagian Selatan di Palembang pada tanggal 18 September 2014.
} 


\section{PENDAHULUAN}

Tinggalan paling menonjol di dataran tinggi Sumatera adalah megalit, yang menjadi sasaran sejumlah penelitian seperti di Lampung (McKinnon, 1993), Pasemah (Hoop, 1932; Sukendar dan Sukidjo, 1983-84; Caldwell, 1997; Kusumawati dan Sukendar, 2000), Dataran Tinggi Jambi (Bonatz dkk., 2006; Budisantosa 2006), dan Dataran Tinggi Sumatera Barat (Micksic, 1986). Situs-situs megalitik di Dataran Tinggi Jambi tersebar di Kabupaten Merangin dan Kerinci, Provinsi Jambi.

Dataran Tinggi Jambi terbentuk oleh Pegunungan Barisan, yang membentang hampir tidak terputus dari Lampung di selatan hingga Aceh di utara. Pegunungan tersebut terbentuk melalui pelipatan tektonik yang disebabkan oleh penunjaman lempeng Samudera Indonesia di bawah Paparan Sunda, sehingga terbentuk dua barisan pegunungan vulkanik yang sejajar (Verstappen, 1973: 66-70). Barisan pegunungan di sebelah barat sambung-menyambung tidak terputus dengan ketinggian sekitar $2.000 \mathrm{~m} \mathrm{dpl}$, sedangkan yang di sebelah timur terputus-putus dengan ketinggian antara 800-1.500 m dpl. Di antara kedua barisan pegunungan tersebut terdapat depresi tektonik yang disebut Sesar Semangko atau Sesar Median. Sesar tersebut membentuk rangkaian lembah-lembah dataran tinggi yang dikelilingi oleh perbukitan, salah satunya adalah Dataran Tinggi Kerinci.

Megalit berbentuk silinder atau kerucut di Dataran Tinggi Jambi pertama kali dilaporkan tahun 1922 oleh pejabat Pemerintah Hindia Belanda bernama. $\mathrm{H}$. Witkamp yang selanjutnya menginformasikan keberadaan megalit Kerinci, yaitu masing-masing di Desa-desa Lempur, Lolo Kecil, dan Muak (Witkamp, 1922: 345-350). Kedua, T. Adam melaporkan lima megalit di marga Pratin Tuo dan Sungai Tenang yang sekarang termasuk Kecamatan Lembah Masurai dan Sungai Tenang, Kabupaten Merangin (Adam, 1922: 380-41). Akhirnya G.K.H. de Bont menyebut secara lebih rinci megalit di Dusun Tuo dan Tanjung Putih (Nilo Dingin), juga sepuluh megalit lainnya di Dataran Tinggi Jambi (Bont, 1922: 31-32). Selanjutnya F.M. Schnitger dalam bukunya yang diterbitkan pertama kali pada tahun 1939 menyebut keberadaan tinggalan megalit di Kerinci seperti di Lempur, Lolo Kecil, Muak, dan 12 megalit di marga Pratin Tuo yang sekarang termasuk Kecamatan Lembah Masurai, Kabupaten Merangin (Schnitger, 1964: 173-176).

Menurut Schnitger, megalit Dataran Tinggi Jambi merupakan monumen pemakaman (Schnitger, 1964: 176). Schnitger membuktikan pendapatnya didasarkan pada tinggalan dari sekitar megalit seperti manik-manik, benda emas, dan mata tombak perunggu yang dianggap benda yang disertakan dalam penguburan. Selanjutnya dikatakannya juga bahwa motif bulatan konsentris pada megalit merupakan pahatan berbentuk gong. Menurut Schnitger, asosiasi antara benda bekal kubur, gong, dan kuburan dapat dilihat pada adat pemakaman kubur batu suku Dayak dan sarkofagus suku Toba. Sementara itu, Van der Hoop dan Van Heekeren menyatakan sebagai menhir rebah dari Zaman Perunggu (Hoop, 1940: 203-204; Heekeren, 1958: 12-99). 


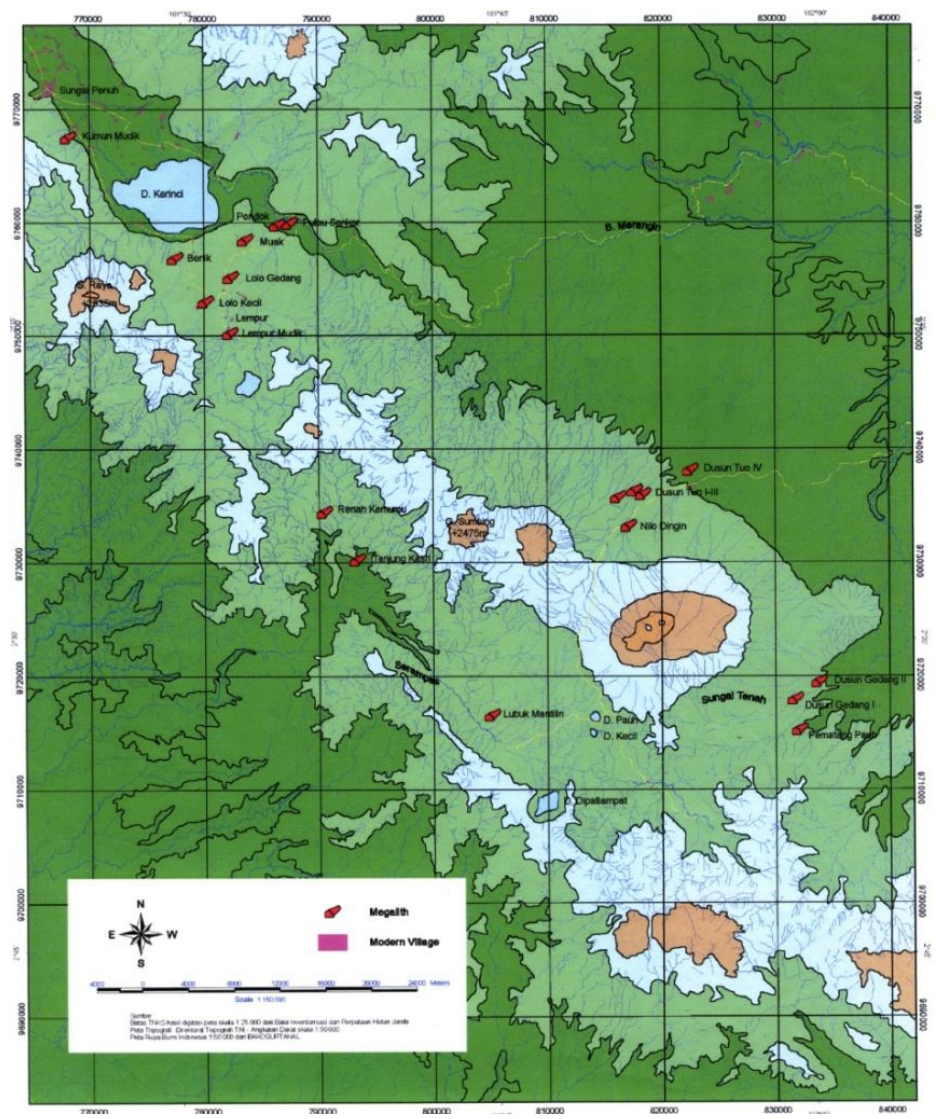

Gambar 1. Peta sebaran megalit silinder dan kerucut di Dataran Tinggi Jambi (Dok. Balar Palembang dan Dominik Bonatz 2006).

Setelah lama berselang, Dataran Tinggi Jambi mulai diperhatikan kembali oleh Suaka Peninggalan Sejarah dan Purbakala Jambi (sekarang Balai Pelestarian Cagar Budaya Jambi) pada tahun 1993. Selain menginventarisasi tinggalan megalit, juga tinggalan Islam seperti masjid dan makam kuno untuk kepentingan perlindungan, pemeliharaan, dan pemugaran. Kemudian Balai Arkeologi Palembang melakukan penelitian dalam tahun 1994 (Prasetyo, 1994/1995). Dalam penelitian tersebut disimpulkan adanya struktur batu yang diduga bekas pemukiman di sekitar megalit. Selanjutnya Dominik Bonatz dari Free University Berlin pada 2003, 2005, 2006, dan 2008 bekerja sama dengan Pusat Penelitian Arkeologi Nasional melakukan penelitian dengan tujuan mengungkap sejarah pemukiman Dataran Tinggi Jambi sejak Pra-Neolitik hingga Awal Islam. Hasil penelitiannya mengungkapkan bahwa bangunan megalitik berfungsi untuk memenuhi kebutuhan ritual sekaligus sebagai lambang status sosial (Bonatz dkk., 2006: 510-512). Selain itu, Bonatz menyatakan bahwa megalitik dan kubur tempayan muncul setelah masa neolitisasi atau sezaman dengan kerajaan Malayu-Sriwijaya (Bonatz, 2012: 54, 62).

Balai Arkeologi Palembang kembali melakukan penelitian arkeologi di Dataran Tinggi Jambi dengan tujuan mengungkap segisegi kehidupan masa lalu seperti 
ekonomi, sosial, dan ideologi. Penelitian megalit dan kubur tempayan di Dataran Tinggi Jambi selama ini telah mengungkapkan empat hal (Budisantosa, 2006: 3254; 2007: 39-49; 2011b: 81-85). Pertama, penulis sependapat dengan Dominik Bonatz dengan tambahan penjelasan bahwa megalitik merupakan objek persembahan kepada kekuatan supernatural (adikodrati) yang bersemayam di gunung-gunung. Kedua, megalit diletakkan di tengah hunian komunitas pendukungnya. Ketiga, megalit berasosiasi dengan kubur tempayan dengan jarak sekitar 400-1.400 m. Hal itu ternyata kemudian didukung dengan data pertanggalan antara kedua situs (Bonatz dkk., 2006: 500, 5002). Keempat, kubur tempayan merupakan ungkapan simbolik dari status sosial dan kepercayaan adanya kehidupan setelah kematian di dunia.

Permasalahan yang belum dibahas adalah apakah penafsiran data arkeologi tentang kepercayaan yang melatari pembuatan megalit dan kubur tempayan Dataran Tinggi Jambi didukung oleh data etnosejarah komunitas setempat? Selanjutnya, bagaimanakah pokokpokok kepercayaan masa lalu yang terungkap dalam data etnosejarah Dataran Tinggi Jambi? Tulisan ini membahas kaitan antara data arkelogi dan data etnosejarah untuk mengungkap lebih jelas fungsi megalit dan kubur tempayan di wilayah tersebut. Penelitian tersebut merupakan pengembangan penelitian arkeologi, khususnya dalam tahap penafsiran data.

Kepercayaan yang melatari pembuatan megalit dan kubur tempayan Dataran Tinggi Jambi berada di dalam alam pikiran komunitas pendukungnya.
Sementara itu, tinggalan budaya material dari masa lalu seringkali tidak mengungkapkan secara langsung alam pikir manusia atau komunitas pembuatnya (Renfrew dan Bahn, 1993: 340). Untuk mengatasi permasalahan tersebut dikembangkan suatu studi yang disebut cognitive archaeology. Dalam masyarakat masa lalu yang telah mengenal tulisan, penggunaan sumber tertulis dapat membantu peneliti mengetahui ideologinya, termasuk di dalamnya kepercayaan. Sementara itu, di Dataran Tinggi Jambi terdapat sumber sejarah, mitologi, dan tradisi ritual yang dapat digunakan untuk mengungkapkan kepercayaan sebelum masuknya Islam.

Kepercayaan (religion) menurut Colin Renfrew dan Paul Bahn adalah "action or conduct indicating a belief in, or reverence for, and desire to please, a divine ruling power" (Renfrew dan Bahn, 1993: 358-359). Renfrew dan Bahn kemudian menyatakan bahwa agama memerlukan suatu kerangka kerja untuk berhubungan dengan kekuatan supernatural yang mempunyai tempat di dalam alam pikiran. Permasalahannya bahwa kepercayaan tidak selalu terungkap dalam tinggalan budaya material. Tindakan yang berkaitan dengan kepercayaan juga sulit dipisahkan dengan kehidupan sehari-hari lainnya. Ada empat aspek untuk mengidentifikan bukti kegiatan ritual masa lalu melalui tinggalan arkeologis (Renfrew dan Bahn, 1993: 359). Pertama, focusing attention. Karena ritual pemujaan dimaksudkan untuk mempertinggi kesadaran tentang kepercayaannya, maka terdapat prasarana yang berkaitan dengan ritual seperti tempat yang dianggap suci dan bangunan yang dipergunakan untuk 
pemujaan serta menciptakan suasana dengan membuat suarasuara dan bau-bauan tertentu yang mendukung pemuja memusatkan pada ritual yang dikerjakan.

Kedua, boundary zone between this world and the next. Alam lain menjadi suatu misteri serta mungkin menyimpan bahaya yang tidak terlihat oleh manusia di dunia. Ritual yang dilakukan mungkin mengalami resiko terkena kekotoran pikiran sehingga dapat menggagalkan hubungannya dengan kekuatan supernatural yang bersemayam di alam lain tersebut. Oleh karena itu perlu pelaksanaan ritual untuk pembersihan dan pencucian.

Ketiga, presence of the deity. Keberhasilan ritual bergantung pada kehadiran kekuatan supernatural yang dipuja. Oleh karena itu, kekuatan tersebut diharapkan kehadirannya atau dihadirkan dalam ritual yang sedang dikerjakan. Salah satu cara untuk mencapai maksud tersebut adalah membuat lambangnya, misal dalam bentuk patung atau benda-benda simbolis lainnya.

Keempat, participation of offerings. Pemujaan merupakan kebutuhan suatu masyarakat, sehingga pemuja berperanserta secara aktif juga dalam menyediakan makanan dan minuman, bahkan persembahan sesaji dan korban kepada kekuatan yang dipuja.

\section{METODE}

Tulisan ini menggunakan data arkeologi yang diperoleh melalui serangkaian penelitian yang penulis lakukan di Dataran Tinggi Jambi pada tahun 2006-2014 serta dilengkapi dengan hasil penelitian di tempat sama yang dilakukan oleh Bagyo Prasetyo (Prasetyo, 1994) dan Dominik Bonatz (Bonatz, 2003; Bonatz dkk., 2006). Data arkeologi yang mungkin terkait dengan fungsi kepercayaan megalit adalah orientasi megalit. Untuk mengetahui apakah orientasi megalit bersifat khtonis (bentang alam) atau kosmis (mata angin), maka dilakukan pengukuran orientasi dengan kompas serta dilakukan pengamatan di lapangan. Berdasarkan pola orientasi megalit dapat dilakukan penafsiran data.

$$
\text { Hasil penafsiran data }
$$
arkeologi dikaitkan dengan data etnosejarah yang meliputi sumber sejarah, mitologi, dan tradisi ritual. Sumber sejarah dapat dikatakan sedikit memberi informasi tentang kepercayaan masa lalu di Kerinci. Sejauh diketahui hanya satu buah piagem yang dikeluarkan oleh Sultan Jambi kepada Depati Sanggaran Agung menyinggung hal tersebut (Voorhoeve, 1970: 398). Meski demikian dokumen tersebut dapat mengungkap fakta tentang alam kepercayaan yang masih hidup di Kerinci pada awal abad ke-18.

Di Dataran Tinggi Jambi terdapat mitologi atau cerita rakyat mengenai megalit. Hal itu telah dicatat dalam buku disertasi antropologi yang disusun oleh John David Neidel di Universitas Yale (2006), juga dicatat oleh Jet Bakels pada tahun 1991 dan 1995 dalam penyususnan disertasi yang kembali dipaparkan dalam tulisannya tahun 2009 (Bakels, 2009: 368-382). Sementara itu, tradisi upacara kenduri pusako (kenduri seko) hingga sekarang masih dilaksanakan komunitas-komunitas Dataran Tinggi Jambi. Dokumentasi kenduri seko paling lengkap dibuat oleh Jet Bakels dengan memilih upacara tersebut di Desa Hyang, Kabupaten Kerinci (Bakels, 2009: 368-382). Data sejarah dan etnografi 
yang selanjutnya disebut etnosejarah ditelusuri untuk mengetahui pokok-pokok kepercayaan komunitas Dataran Tinggi Jambi masa lalu sebelum masuknya Islam.

\section{HASIL DAN PEMBAHASAN}

Dalam surat yang ditulis oleh Sultan Jambi kepada Depati Sanggaran Agung, Kerinci, pada tahun 1707, disebutkan adanya perintah Sultan agar antara lain depati tidak mengorganisasi penyelenggaraan pesta tari-tarian dan menyembah patung batu dari dewa-dewa dan semua perbuatan yang dilarang oleh ajaran agama Islam (Voorhoeve, 1970: 398). Surat Sultan Jambi tersebut menunjukkan bahwa pada masa awal Islam di Kerinci masih terdapat sisa-sisa kepercayaan lama, yaitu penyembahan berhala. Di Kerinci pernah ditemukan dua buah patung Boddhisattwa perunggu (Schnitger, 1937: 13), tetapi terbukti agama Buddha tidak berkembang di Dataran Tinggi Jambi. Dengan demikian, patung batu yang dimaksud oleh Sultan Jambi diduga bukan patung Buddha melainkan megalit.

Dalam penelitian fungsi megalit Dataran Tinggi Jambi digunakan data orientasi megalitik. Data orientasi megalit wilayah tersebut dapat dipaparkan dalam Tabel 1.

Tabel 1: Data Orientasi Megalitik Dataran Tinggi Jambi

\begin{tabular}{|c|c|c|c|}
\hline No & Situs Megalitik & $\begin{array}{c}\text { Orientasi } \\
\text { Mata } \\
\text { Angin } \\
\end{array}$ & $\begin{array}{l}\text { Orientasi } \\
\text { Khtonis }\end{array}$ \\
\hline 1 & Kumun Mudik & $30^{\circ} \mathrm{U}$ & Bukit Adam \\
\hline 2 & Tanjung Batu & $320^{\circ} \mathrm{U}$ & Gunung Kerinci \\
\hline 3 & Batu Patah Muak & $340^{\circ} \mathrm{U}$ & Gunung Kerinci \\
\hline 4 & Lolo Gedang & $210^{\circ} \mathrm{U}$ & $\begin{array}{c}\text { Gunung Kunyit/ Gunung } \\
\text { Raya }\end{array}$ \\
\hline 5 & Lempur & $190^{\circ} \mathrm{U}$ & Gunung Kunyit \\
\hline 6 & Pulau Sangkar & $330^{\circ} \mathrm{U}$ & Gunung Kerinci \\
\hline 7 & Dusun Tuo & $244^{\circ} \mathrm{U}$ & Gunung Hulu Nilo \\
\hline 8 & Pematang Sungai Nilo & $250^{\circ} \mathrm{U}$ & Gunung Hulu Nilo \\
\hline 9 & Nilo Dingin (Tanjung Putih) & $295^{\circ} U$ & Gunung Sumbing \\
\hline 10 & Talang Jambu Abang & $20^{\circ} \mathrm{U}$ & Gunung Sumbing \\
\hline 11 & Bukit Batu Larung & Baratlaut & Gunung Garakah \\
\hline
\end{tabular}


Berdasarkan data di Tabel 1 dapat diduga bahwa megalit merupakan objek pemujaan yang berkaitan dengan kekuatan supernatural yang bersemayam di gunung (Budisantosa, 2006: 52).

Penduduk Kerinci seperti di Muak, Pondok, dan Pulau Sangkar menamai megalit tersebut dengan batu patah karena keadaannya patah. Adapun penduduk Lolo Gedang, Lempur, dan Kumun menamai batu gong berdasarkan adanya relief lingkaran konsentris yang dianggap sebagai gambar gong. Penduduk Serampas, Sungai Tenang, dan Pratin Tuo, Kabupaten Merangin menamainya sebagai batu larung dan batu galeh. Sejumlah informan mengartikan kata larung dengan 'rongga', sedangkan galeh diartikan 'keranjang' (Bonatz dkk., 2006: 509-510). Hal itu menunjukan bahwa penduduk setempat sendiri sebenarnya tidak mengetahui secara
Di Jawa Tengah dan Yogyakarta kata larung adalah kata kerja berarti mempersembahkan benda-benda sesaji kepada kekuatan supernatural yang dipercaya menguasai tempat tertentu, khususnya sungai atau laut. Dengan demikian batu larung merupakan batu yang digunakan untuk meletakkan persembahan (Budisantosa, 2006: 52).

Menurut mitologi Dataran Tinggi Jambi, penguasa gununggunung itu disebut dengan nenek yang mempunyai kesaktian (Neidel, 2006: 403-404), atau mambang, ialah makhluk halus yang pertama kali menghuni (Bakels, 2009: 368). Di antara nenek itu pernah berperang, sehingga disebut 'perang gunung'. Salah satu contoh perang gunung terjadi antara Nenek Wali Mantring Baju Temago yang bersemayam di Gunung Sumbing dengan Nenek Serampu Alam Sati yang bersemayam di Gunung

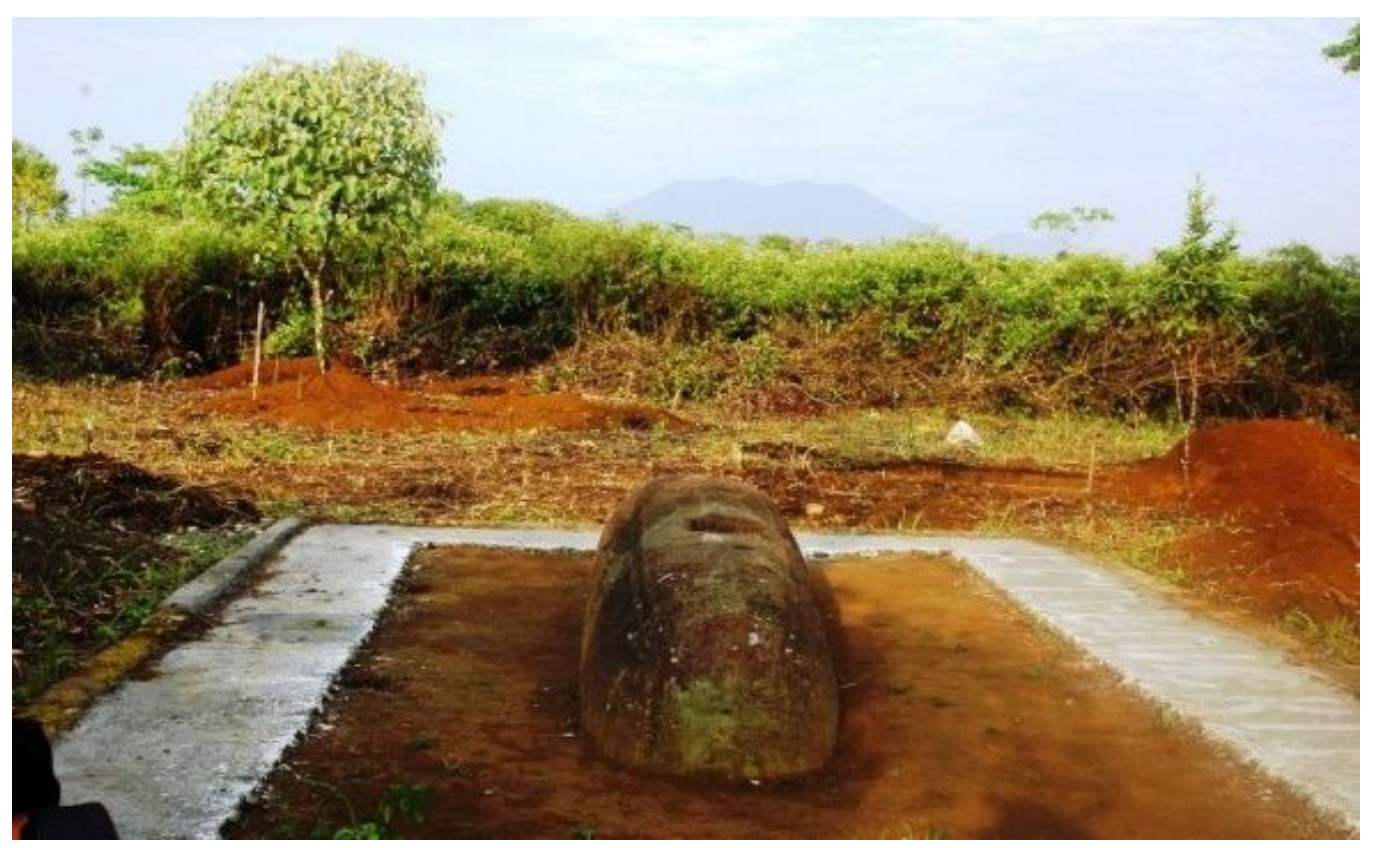

Gambar 2. Foto contoh bangunan megalitik silinder dari Dusun Tuo, Kabupaten M erangin yang menghadap ke arah Gunung Hulu Nilo (Dok. Balar Palembang 2006)

jelas arti kata larung, tetapi kata itu justru diduga nama sebenarnya yang diberikan oleh pendahulunya.
Garakah. Paling sedikit satu buah peluru berbentuk megalit berhasil menghantam puncak Gunung 
Sumbing, sehingga menjadi sumbing.

Bentuk megalitik Dataran Tinggi Jambi adalah silinder atau kerucut yang diletakkan dalam posisi rebah. Berdasarkan pengamatan sejumlah megalit insitu dapat diketahui bahwa bagian dasar megalit merupakan bidang yang datar. Selanjutnya, hasil pengamatan atribut bentuk dan motif hias relief megalit Dataran Tinggi Jambi tidak memberi petunjuk bagaimana kepercayaan dan ritual tersebut dilaksanakan. Motif reliefnya pun belum dapat diketahui makna religiusnya, tetapi sebagian mungkin berfungsi dekoratif, seperti lingkaran-lingkaran konsentris diambil dari motif hias nekara perunggu Tipe Heger I (Schefold, 2009: 399-400). Motif bintang yang dipahat di tengah lingkaran-lingkaran konsentris pun diduga meniru motif hias nekara perunggu Dong Son (Bakels, 2009: 375; Budisantosa, 2011b: 52-53).

$$
\text { Motif lainnya adalah }
$$

rangkaian motif hias manusia kangkang yang ditafsirkan oleh Heinzpeter Znoj sebagai lambang kesinambungan generasi (Znoj, 2001: 3012), tetapi mungkin juga melambangkan dunia bawah/alam arwah sebagaimana dipahatkan pada sarkofagus-sarkofagus di Bunutin dan Tamanbali, Bali dalam bentuk buta sungsang yang dipercaya sebagai makhluk pelindung arwah orang meninggal dari kekuatan jahat (Soejono, 1977: 161-162). Soejono memperkuat dugaannya dengan menyatakan bahwa pahatan buta sungsang ditemukan juga pada tempat-tempat yang berhubungan dengan kematian, seperti misalnya di pura dalem di Bakung dan Banyuning, Bali. Sementara itu, tokoh manusia dalam bentuk utuh atau wajah hingga bahu ditemukan juga pada sejumlah megalit Dataran Tinggi Jambi. Sikap gambar tokohnya pun beragam seperti berdiri tegak sambil memegang senjata (pedang dan gada), menari, dan bersikap siap berperang sambil membawa pedang dan perisai. Relief seperti itu mungkin dimaksudkan untuk menggambarkan kepahlawanan nenek moyangnya.

Unsur-unsur utama dalam ritual megalit agaknya masih bertahan pada tradisi kenduri seko yang masih dilaksanakan hingga sekarang. Kenduri seko merupakan ritual untuk menjalin hubungan dengan penguasa pertama Alam Kerinci dan nenek moyang (Bakels, 2009: 370-371). Upacara tersebut dilaksanakan juga untuk memperingati pendirian desa, mengungkapkan rasa terima kasih atas hasil panen padi, dan sebagai arena komunitas pelantikan kepala desa/dusun baru (depati atau kerio/rio). Dalam kenduri seko dilaksanakan pemotongan hewan korban berupa seekor kerbau serta digelar tari-tarian. Dalam kenduri seko dilakukan pula upacara pembersihan pusaka, antara lain prasasti daun lontar atau tanduk kerbau, tombak, pedang, golok, jimat, keramik Cina, dan barang berharga lainnya. Pusaka merupakan bagian dari sejarah desa, dan dipercaya sebagai warisan nenek moyang pendiri desa. Sehari-hari pusaka disimpan di loteng rumah, diikatkan pada tiang bagian tengah rumah depati (kepala desa) atau rio (kepala dusun).

Menurut informasi yang diperoleh, Jet Bakels menyatakan bahwa contoh kenduri seko yang dilaksanakan di Desa Hyang Tinggi, Kerinci dahulu dilaksanakan di sekitar megalit yang disebut pulu negeri, pulung negeri, atau kepala 
negeri (Bakels, 2009: 371-375). Megalit tersebut dibangun dari bongkahan batu yang disusun di atas tanah membentuk gundukan berdenah empat persegi panjang. Kadangkala di bagian atasnya dipasang tiang batu. Bakels mendapatkan informasi dari penduduk bahwa tempat tersebut dipercaya sebagai tempat suci dan tempat persembahan yang pertama kali dibangun oleh pasangan nenek moyangnya, yaitu seorang pendatang laki-laki dan puteri mambang. Pendiriannya untuk menyampaikan kepada para seperti manusia, apakah itu lebih baik atau buruk, lebih besar atau kecil, lebih cantik atau jelek, bergantung pada konteksnya (Bakels, 2009: 369-370). Mereka berdiam di gunung dan hutan, seringkali disebut nenek. Keberadaannya kadangkala dapat dilihat dengan mata. Sementara itu, nenek moyang orang Kerinci adalah seorang lelaki pendatang dari kerajaan-kerajaan yang jauh dan yang menikah dengan seorang perempuan mambang, yaitu seorang peri cantik yang berdiam di hutan. Nenek moyang itu berbeda-beda

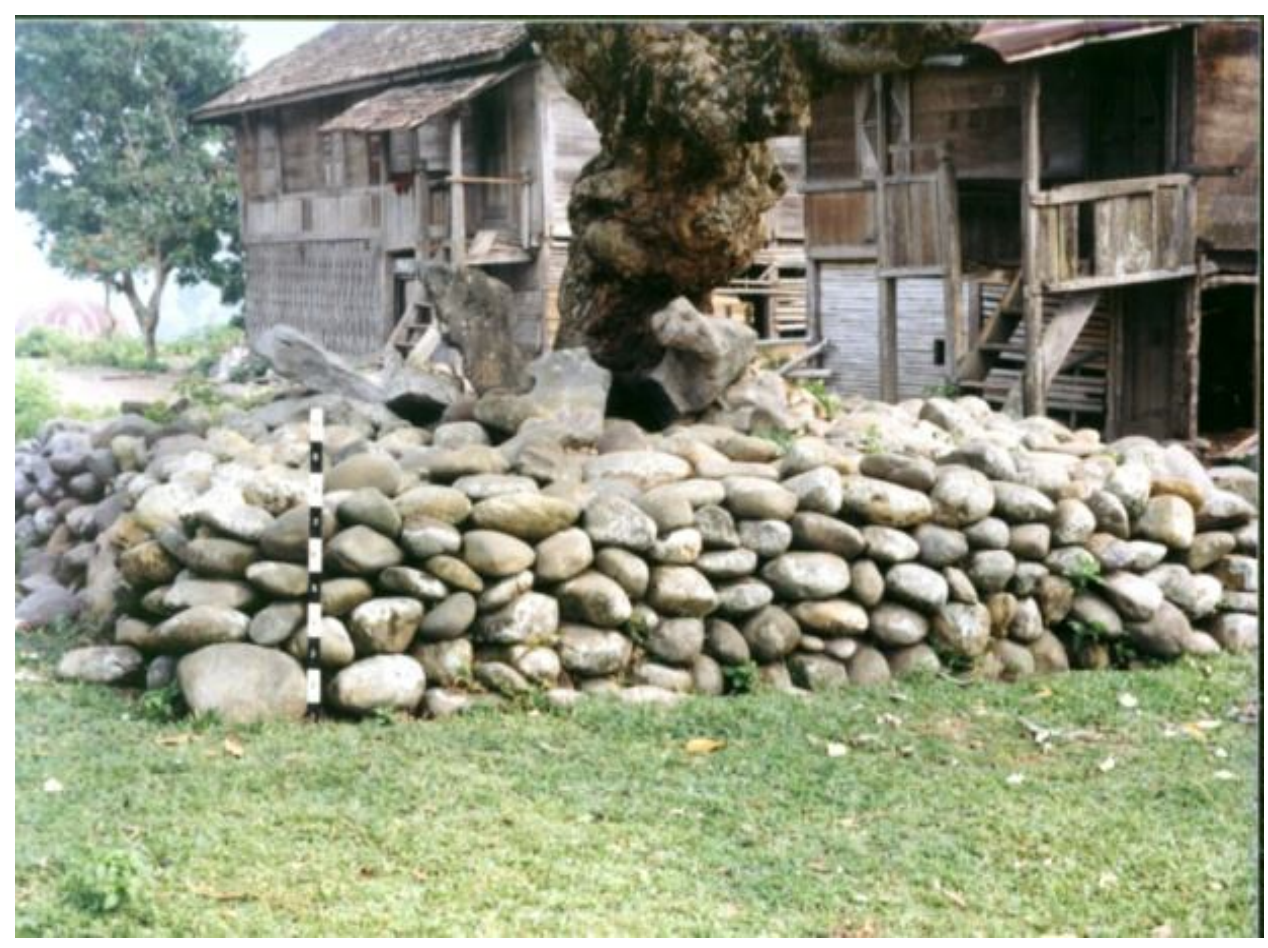

Gambar 3. Foto susunan batu kali berdenah segi empat yang disebut pulung negeri; dahulu dipergunakan sebagai pusat ritual kenduri seko. Tinggalan ini ditemukan di Desa Hyang, Kabupaten Kerinci (Sumber: Dok. Balar Palembang 1994).

mambang bahwa tanah di sekitar pulu negeri telah didiami manusia sebagai penghuni baru.

Menurut mitologi pada zaman purba wilayah Kerinci yang disebut 'Alam Kerinci' hanya dihuni oleh mambang atau bunian, yaitu makhluk halus yang mempunyai sifat asalnya seperti dari Pagaruyung dan Jawa-Mataram. Untuk menjaga hubungan dengan mambang dan arwah nenek moyang, dalam kenduri seko dilaksanakan tari-tarian dengan memanggil nama nenek moyang hingga tidak sadarkan diri. Kata-kata yang keluar dari mulut penari yang 
tidak sadar diri dipercayai merupakan pesan dari nenek moyang serta sebagai tanda telah terajalinnya kembali kedekatan hubungan antara nenek moyang dan keturunannya. Karena arwah nenek moyang berubah menjadi harimau, maka penari yang dipercaya telah dikuasai atau dimasuki oleh arwah nenek moyang kadang-kadang mengaum seperti harimau. Pada malam hari dilakukan tari-tarian serta dipersembahkan daging dan darah (kerbau) yang diletakkan di pinggir desa untuk para arwah nenek moyang.

Dalam momen pelantikan kepala desa/dusun (depati atau rio) yang dilaksanakan dalam kenduri seko dilakukan pengucapan sumpah suci (karang setia) yang menandai persekutuan antara manusia dan arwah-arwah. Para arwah tidak hanya sebagai pihak yang menyetujui persekutuan, tetapi juga sebagai pengawal sumpah. Menyusul pengucapan karang setia, para arwah mengucapkan sumpah kutukan (perbayo sumpah) yang akan mengenai orang yang melanggar sumpah suci (karang setia). Untuk menandai peristiwa tersebut dikorbankan seekor kerbau, dan kepalanya ditanam di sekitar tempat upacara sebagai persembahan kepada para arwah. Arwah kerbau dipercaya menjadi saksi persumpahan. Sebagian dagingnya dimasak untuk dimakan bersama komunitas desa yang berperan serta dalam persekutuan, dan sebagian daging segar diletakkan di pinggir desa untuk dipersembahkan kepada para arwah.

Bakels menduga bahwa kepala negeri lebih dahulu ada sebelum megalit berbentuk silinder atau kerucut. Selanjutnya dinyatakan bahwa megalit silinder atau kerucut dibawa pendatang baru yang mempunyai kebiasaanya sendiri. Oleh karena itu, fungsi kepala negeri masih dapat diketahui hingga sekarang, sedangkan fungsi megalit silinder atau kerucut tidak diketahui lagi (Bakels, 2009: 380). Sementara itu, penulis beranggapan bahwa kepala negeri dan megalit silinder atau kerucut merupakan budaya megalit yang pada dasarnya dibuat untuk tujuan yang sama. Dengan pertimbangan tertentu kepala negeri dibuat dengan alasan pada sulitnya bahan batuan berukuran besar yang ada di Desa Hyang Tinggi yang merupakan lembah dengan lingkungan lahan basah. Selain itu, ritual kenduri seko hingga kini tidak hanya ditemukan di komunitas desa sekitar tinggalan kepala negeri, tetapi juga di komunitas desa sekitar tinggalan megalit silinder atau kerucut.

Tinggalan arkeologi seperti pecahan gerabah, keramik asing, manik-manik, alat serpih obsidian, batu giling, dan alat besi ditemukan di sekitar megalit. Tinggalan tersebut ditemukan dalam ekskavasi di situs Pondok (Bonatz, 2003), Bukit Batu Larung (Bonatz dkk., 2006: 497500), Dusun Tuo (Budisantosa, 2006: 48-49), Talang Alo, Jambu Abang (Budisantosa, 2007: 42-45), Batu Patah Muak (Budisantosa, 2009: 22-28), dan Pematang Sungai Nilo (Budisantosa, 2012: 67-86). Di Pondok ditemukan juga lubang tiang rumah (Bonatz, 2003), sedangkan di Batu Patah Muak ditemukan batu sendi (umpak tiang rumah) dalam posisi in situ (Budisantosa, 2009: 19). Berdasarkan data arkeologi tersebut dapat diketahui bahwa hunian berada di sekitar megalit. Hal itu sesuai dengan pembuatan kepala negeri yang dimaksudkan sebagai tanda bahwa tanah di sekitarnya telah dihuni oleh nenek moyangnya, 
yaitu seorang lelaki pendatang yang menikahi seorang puteri mambang. Sebagai sebuah tradisi, keturunannya akan melakukan hal yang sama ketika membuka area baru untuk dijadikan perkampungan (desa). Kepercayaan bahwa megalit merupakan tempat suci serta mendapat perlindungan arwah nenek moyang mungkin masih tersisa hingga sekarang di Dataran Tinggi Jambi sebagaimana terlihat dari penduduk Desa Lempur mengungsi ke sekitar megalit ketika mengalami kepanikan menghadapi gempa bumi pada tanggal 1 Oktober 2009 (Yeni binti Surname, komunikasi pribadi tanggal 2 Oktober 2009).

Hasil penelitian kubur tempayan di Dataran Tinggi Jambi telah mengungkapkan bahwa kubur tempayan berasosiasi dengan megalit sebagaimana terlihat di Renah Kemumu (Bonatz dkk., 2006: 500, 502), Lubuk Mantilin (Budisantosa, 2007: 44), Lolo Gedang (Budisantosa, 2011b: 91-
95), dan Muak (Budisantosa, 2009, 2011a). Simpulan tersebut didukung dengan data pertanggalan antara megalit di Situs Bukit Batu Larung dan kubur tempayan di Renah Kemumu (Bonatz dkk., 2006: 500, 502). Situs megalitik berumur sekitar $970 \pm 140$ BP (1950) dengan radiokarbon, atau dengan opticallystimulated luminescence (OSL) 1200 $A D$, sedangkan kubur tempayan berumur $810 \pm 120 \mathrm{BP}$ (1950) dengan radiokarbon, atau dengan OSL $850 \pm 110$ BP. Selanjutnya diketahui jarak antara hunian dan kubur tempayan antara 400-1.400 m. Di dalam kubur tempayan ditemukan benda-benda yang diduga berfungsi sebagai bekal kubur bagi arwah seperti wadah tembikar, manikmanik kaca dan batu karnelian, serta benda perunggu (Budisantosa, 2008, 2011b: 82; Azis, 2010: 24).

Berdasarkan data tersebut dapat disimpulkan bahwa kubur tempayan merupakan cermin kepercayaan akan adanya alam kehidupan selanjutnya yang akan

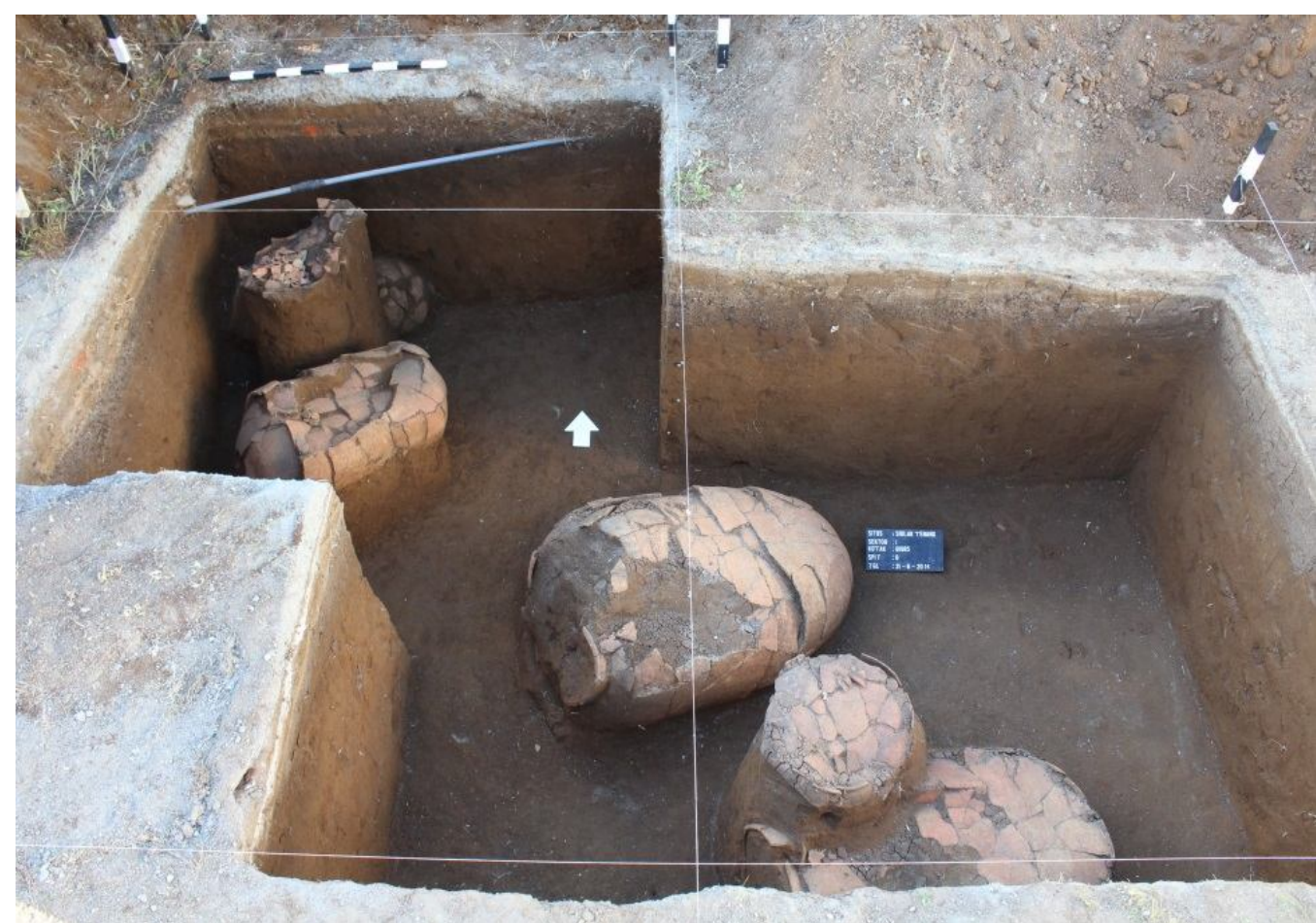

Gambar 4. Foto Salah Satu Hasil Ekskavasi Kubur Tempayan di situs Siulak Tenang, Kerinci (Dok Balar Palembang 2014). 
dihuni oleh orang yang telah meninggal dunia. Kubur tempayan dibuat sebagai sarana mengantarkan arwah seseorang menuju alam berikutnya. Dalam mitologi Kerinci, alam arwah tersebut merupakan tempat bersemayam para mambang, yaitu penghuni pertama Alam Kerinci, dan nenek moyang pertama yang menikah dengan puteri mambang serta para arwah keturunannya. Pada ritual kenduri seko anak keturunannya menjalin kembali hubungan yang erat dengan para mambang dan pendahulunya.

\section{SIMPULAN}

Penafsiran data arkeologis mengenai kepercayaan yang melatari pembuatan megalit dan kubur tempayan Dataran Tinggi Jambi ternyata didukung dengan data etnosejarah. Orientasi megalit ke gunung-gunung menunjukkan bahwa gunung-gunung merupakan tempat bersemayam kekuatan supernatural, ialah arwah leluhur, baik dari jenis manusia maupun makhluk halus yang telah mendiami Dataran Tinggi Jambi sebelum leluhur (nenek moyang) manusia bermukim di wilayah tersebut. Leluhur komunitas-komunitas pendukung budaya megalitik Dataran Tinggi Jambi ternyata tidak hanya satu orang, tetapi sejumlah orang yang masing-masing bersemayam di gunung tertentu. Pada masa lalu megalit diduga merupakan pusat ritual suatu komunitas untuk menghormati dan menjaga hubungan baik dengan arwah leluhur. Dalam ritual tersebut dipersembahkan sesaji yang mungkin berupa hewan korban (kerbau). Persembahan korban merupakan inti dari ritual tersebut, oleh karena itu megalit diberi nama batu larung yang kurang lebih berarti batu yang digunakan sebagai pusat ritual persembahan korban. Batu larung diduga nama yang diberikan pada megalit dalam konteks budaya pada masanya. Nama tersebut bertahan secara turun-temurun hingga kini.

Berdasarkan data arkeologi dapat diketahui bahwa kubur tempayan merupakan cara penguburan kerangka manusia yang dilakukan oleh komunitas pendukung budaya megalitik. Benda-benda yang disertakan dalam penguburan menunjukkan bahwa benda-benda tersebut dipercaya sebagai benda yang digunakan oleh arwah dalam kehidupannya di alam arwah. Apakah arwah para keturunan bersemayam juga di gunung-gunung bersama leluhurnya, hal itu tidak diceritakan dalam mitologi. Meski demikian dapat diketahui secara jelas bahwa dalam mitologi Dataran Tinggi Jambi terdapat kepercayaan akan adanya alam arwah, sedangkan arwah dapat menentukan alam kehidupan manusia.

Berdasarkan hasil penelitian dapat diketahui bahwa sisa-sisa budaya lama intangible masih terpelihara di kalangan penduduk setempat, tetapi mereka sendiri tidak mengetahui atau menyadari keterkaitannya dengan budaya megalitik dan kubur tempayan. Sisa kepercayaan di wilayah tersebut terlihat mengalami kesinambungan, meski agama Islam telah menggantikan kepercayaan lama. Kepercayaan yang tidak berakar pada ajaran Islam dan yang bertahan dalam mitologi dan tradisi diduga kuat merupakan sisa kepercayaan yang pernah hidup dan berkembang serta menjadi konsep yang melandasi pembuatan megalit dan kubur tempayan pada masa lampau. 


\section{SARAN}

Penelitian

tentang

kesinambungan budaya di Dataran Tinggi Jambi dapat diperluas pada budaya tangible dan intangible lainnya, sehingga pengetahuan tentang hal tersebut semakin lengkap. Kesinambungan atau keterkaitan budaya masa kini dengan budaya masa lalu dapat dijadikan bahan untuk meningkatkan kesadaran sejarah dan budaya masyarakat. Dengan kesadaran mengenai hal tersebut diharapkan masyarakat meningkatkan kepedulian dan apresiasi pada pelestarian dan penelitian arkeologi. Pemerintah setempat pun perlu didorong untuk berperan serta secara aktif dalam pelestarian dan pemanfaatannya. 


\section{DAFTAR PUSTAKA}

Adam, T. 1922: "Oudheden te Djambi II", Oudheidkundig Verslag 1: 38-41.

Azis, Fadhila Arifin. 2010: "Potensi Situs Arkeologi Kawasan Kerinci, Jambi: Ikon Budaya Austronesia", Amerta, 28. Jakarta: Pusat Penelitian dan Pengembangan Arkeologi Nasional, hal. 17-44.

Bakels, Jet. 2009: "Kerinci's Living Past: Stones, Tales, and Tigers." Dalam From Distant Tales: Archaeology and Ethnohistory in the Highlands of Sumatra, Dominik Bonatz, John Miksic, John David Neidel, Mai Lin TjoaBonatz (Ed.).). Newcastle: Cambridge Scholar Publishing, hal. 367-382.

Bonatz, Dominik., John David Neidel, Mai Lin Tjoa-Bonatz. 2006: "The megalithic complex of highland Jambi: An archaeological perspective." Dalam Bijdragen tot de Taal-, Land- en Volkenkunde (BKI) 162-4: 490-522. Koninklijk Instituut voor Taal-, Land- en Volkenkunde.

Bonatz, Dominik. 2012: "A Highland Perspective on the Archaeology and Settlement History of Sumatra," Archipel 84: 35-81. Paris: L'Ecole des Hautes en Sciences Sociales.

Bont, G.K.H. de. 1922: "De batoe's larong (kist-steenen) in Boven Djambi, Onderafdeeling Bangko",Nederlandsch-Indië Oud en Niew 7: 31-32.

Budisantosa, Tri Marhaeni S. 2006: "Aspek-aspek Kehidupan Tradisi Megalitik Dataran Tinggi Jambi," Siddhayatra 11(2):32-54. Palembang: Balai Arkeologi Palembang.

Budisantosa, Tri Marhaeni S. 2007: "Pola Budaya Megalitik di Situs Talang Alo dan Talang Jambu Abang, Kabupaten Merangin, Provinsi Jambi," Siddhayatra 12(2): 39-49. Palembang: Balai Arkeologi Palembang.

Budisantosa, Tri Marhaeni S. 2008: Laporan Ekskavasi Situs Lolo Gedang, Kerinci, Jambi. Palembang: Balai Arkeologi Palembang.

Budisantosa, Tri Marhaeni S. 2009: Laporan Penelitian Megalitik Situs Muak, Kabupaten Kerinci, Provinsi Jambi. Palembang: Balai Arkeologi Palembang.

Budisantosa, Tri Marhaeni S. 2011a: Laporan Penelitian Kubur Tempayan di Desa Muak, Kabupaten Kerinci, Provinsi Jambi. Palembang: Balai Arkeologi Palembang.

Budisantosa, Tri Marhaeni S. 2011b: "Megalit dan Kubur Tempayan di Dataran Tinggi Jambi: Situs Lolo Gedang, Kerinci." Dalam Asia Tenggara dalam Perspektif Arkeologi, Inajati Adrisijanti (Ed.). Palembang: Balai Arkeologi Palembang, hal. 36-106. 
Budisantosa, Tri Marhaeni S. 2012: "Situs Pematang Sungai Nilo dalam Hubungan dengan Situs-situs Lainnya di Dataran Tinggi Jambi", Siddhayatra, 17(1): 67-86. Palembang: Balai Arkeologi Palembang.

Caldwell, lan. 1997: "A rock carving and a newly discovered stone burial chamber at Pasemah,Sumatra". Dalam Bijdragen tot de Taal-, Land-, en Volkenkunde 153:169-82.

Heekeren, H.R. van. 1958: The Bronze-iron Age of Indonesia. 's-Gravenhage: Nijhoff (KITLV, Verhandelingen 22).

Hoop, A.N.J.Th a van der. 1932: Megalitische Oudheden in Zuid-Sumatra. Ph. D thesis, Utrecht University. Zutphen: Thieme.

Hoop, A.N.J. Th.a Th. van der. 1940: Prehistoric site near the Lake Kerinchi (Sumatra), dalam F.N. Chasen dan M.W.F. Tweedie (Ed.), Proceedings of the Third Congress of Prehistorians of the Far East, hlm: 200-4. Singapore: Government Press.

Kusumawati, Ayu dan Haris Sukendar. 2000: Megalitik Bumi Pasemah; Peranan serta Fungsinya. Jakarta: Proyek Pengembangan Media Kebudayaan Direktorat Jenderal Kebudayaan Departemen Pendidikan Nasional Republik Indonesia.

McKinnon, E.E. 1993: "A note on finds of early Chinese ceramics associated with megalithic remains in Northwest Lampung", Journal of Southeast Asian Studies 24-2:227-38.

Micksic, John. 1986: "A Valley of megaliths in West Sumatra; Mahat (Schnitger's Aoer Doeri), Journal of Malaysian Branch of the Royal Asitic Society 59: 27-32.

Neidel, John David. 2006: "The garden of forking path; History, its erasure and remembrance in Sumatra's Kerinci Seblat National Park," Ph D Thesis, Yale University, New Haven, CT.

Prasetyo, Bagyo. 1994/1995: "Laporan Penelitian Situs Plawangan, Rembang, Jawa Tengah (1980-1993)," dalam Berita Penelitian Arkeologi Nomor 43. Jakarta: Pusat Penelitian Arkeologi Nasional.

Renfrew, Colin dan Paul Bahn. 1993: Archaeology: Theories, Methods and Practice. London: Thames and Hudson Ltd.

Schefold, Reimar 2009: "Kerinci Traditional Architecture," Dalam From Distant Tales: Archaeology and Ethnohistory in the Highlands of Sumatra, Dominik Bonatz, John Miksic, John David Neidel, Mai Lin Tjoa-Bonatz (Editors). Newcastle: Cambridge Scholar Publishing, hal. 383-401.

Schnitger, F.M. 1937: The Archaeology of Hindoo Sumatra. Leiden, E.J. Brill.

Schnitger, F.M. 1964: Forgotten Kingdoms in Sumatra. Leiden: E.J Brill. 
Soejono, R.P. 1977: "Sistim-sistim Penguburan Pada Akhir Masa Prasejarah di Bali," Dissertasi Fakultas Sastra, Universitas Indonesia, Jakarta.

Sukendar, Haris dan Sukidjo. 1983/1984: Naskah Studi Kelayakan Megalith Pasemah di Tinggi Harri, Kabupaten Lahat. N.p.: Departemen Pendidikan dan Kebudayaan Kantor Wilayah Propinsi Sumatra Selatan.

Verstappen, H.Th. 1973: A Geomorphological reconnaisance of Sumatra and adjacent island (Indonesia). Groningen: Wolters-Noordhodd. (Royal Dutch Geographical Society, Verhandelingen 1).

Voorhoeve, P. 1970: "Kerinci Documents". Dalam BKI 126-4: 369-399. Koninklijk Instituut voor Taal-, Land- en Volkenkunde.

Witkamp, H. 1922: 'Drie 'steenen kanonnen', Zuid-Kerintji, Tijdschrift van het Koninklijk Nederlandsch Aardrijkskundig Genootschap 29: 340-350.

Znoj, Heinzpeter. 2001: Heterarchy and domination in highland Jambi; The contest for community in a matrilinear society. Habilitation Thesis, University of Bern. 